\title{
Wittgenstein and Sebald: The Place of Home and the Grammar of Memory
}

\author{
David Schalkwyk, Cape Town
}

On page three of three of W.G. Sebald's novel, Austerlitz, four pairs of eyes gaze out at the reader. Two are nocturnal animals; the other pair is human, readily identifiable as the artist Jan Peter Tripp and the philosopher Ludwig Wittgenstein. ${ }^{1}$ Sebald's narrator tells us, "all I remember of the denizens of the Nocturama is that several of them had strikingly large eyes, and the fixed, enquiring gaze found in certain painters and philosophers who seek to penetrate the darkness which surrounds us purely by means of looking and thinking". This is the first time Wittgenstein is mentioned in the novel, and he maintains a constant, if enigmatic, presence, as he does throughout Sebald's work. He reappears in Austerlitz when the narrator informs us of his striking resemblance to the protagonist:

[W]henever I see the a photograph of Wittgenstein somewhere or other, I feel more and more as if Austerlitz were gazing at me out of the it, and when I look at Austerlitz it is as if I see in him the disconsolate philosopher, a man locked into the glaring clarity of his logical thinking as inextricably as into his confused emotions, so striking is the likeness between them. (56)

This resemblance is more than an affinity of facial features: it is more like an identity of constitution, a mode of being in the world, in which "confused emotions" are as significant as the "glaring clarity of logical thinking".

Further invocations of Wittgenstein are more subtle, but hardly less striking. Jacques Austerlitz's London house is furnished, almost to the last detail, in the austere style with which Wittgenstein decorated (if that is the word) his own rooms in Cambridge. More significant than the similarities of physiognomy or aesthetic disposition, however, is Jacques Austerlitz's

\footnotetext{
${ }^{1}$ See Sears 2007, 219.

${ }^{2}$ Sebald 2001, 3.
} 
Wittgensteinian mode of trying to make sense of the world in which he also finds himself so ill at ease. Wittgenstein writes in the Preface to the Philosophical Investigations that his attempts, to use Sebald's words, to "penetrate the darkness which surrounds us purely by means of looking and thinking" amounts to no more than a "number of sketches of landscapes ... made in the course of ... long and involved journeying ... an album ... of a wide field of thought criss-cross in every direction ... the lot [of which] in its poverty and in the darkness of this time [may be] to bring light into one brain or other-but, of course", he adds with characteristic pessimism, "it is not likely". Austerlitz's own "investigations", Sebald's narrator informs us, "had long outstripped their original purpose as a project for a dissertation, proliferating in his hands into an endless preliminary sketches for a study ... of the family likenesses between" the structures of capitalist architecture (44). This work finally leads Austerlitz to a psychic breakdown: "Austerlitz ... sat here for hours, laying out these photographs or others from his collection ... arranging them in an order depending on their family resemblances, or withdrawing them from the game until there was nothing left but the grey table top, or he felt exhausted by the constant effort of thinking and remembering" (168).

The intellectual restlessness that Wittgenstein records in his preface is matched by his personal and cultural agitation, by his state of almost permanent exile and rootlessness. ${ }^{4}$ Marjorie Perloff points out with great perspicuity that, "Only someone who is not fully at home in the world will talk as much as Wittgenstein does about 'the language game which is one's original home"". ${ }^{5}$ Perloff connects this sense of strangeness not only with Wittgenstein's alienation as an Austrian in England but also to his foreignness, "as a Jew, in the Vienna of his birth" (Perloff 1999, 76). Wittgenstein's Jewishness is a controversial issue. Whatever one thinks of David Stern's assertion that "Wittgenstein saw in Weininger, and Weininger's

${ }^{3}$ Wittgenstein 1953, ix-x.

${ }^{4}$ Such a feeling of exile is noted even when he was in Austria fighting during the First World War: "This kind, friendly letter opens my eyes to the fact that I am living in exile here" (MS 103, pp. 17v-18v, July 26, 1916, Wittgenstein 1991, 47). For a thorough study of Wittgenstein's status as an exile, see James C. Klagge, Wittgenstein in Exile (unpublished manuscript).

${ }^{5}$ Perloff 1999, 76. 
anti-Semitism a mirror of his own self-hatred, a way of figuring a relationship of identification and denial that he both had to and could not confront", ${ }^{6}$ it seems that this aspect of Wittgenstein's state of exile-from himself as much as any country or culture - resonates throughout Sebald's work and through characters as various as Jacques Austerlitz and Paul Bereyter, Max Ferber and the Sebaldian narrator himself. ${ }^{7}$ Wittgenstein is the biographical source of many things central to Sebald's quest, not least of which is the "moral radicalism" that, in the author's words, binds the young Wittgenstein as primary school teacher in the Austrian Alps and the teacher of Sebald's own Tyrolian childhood, who, being a quarter Jewish and temperamentally deeply alienated from the village community, finally succumbed to his experience of internal exile by taking his own life.

I have argued elsewhere, following Perloff, that Wittgenstein's attempts to return language to its proper home invariably reveals the uncanny within the familiar or the ordinary, or to adopt Freud's terms, that what is heimlich is also likely to be unheimlich. ${ }^{9}$ For Sebald the play of home and exile, the familiar and the uncanny, is inseparable from the demands and evasions of memory. Wittgenstein's role in Sebald's texts con-

${ }^{6}$ Stern 2001, 259.

${ }^{7}$ Paul Bereyter, the primary school teacher in the Alpine village who ends up taking his own life - a constant obsession of all of Sebald's protagonists, as it was with Wittgenstein - is based on Sebald's own teacher in the Alpine village of Wertach. But Sebald declares in two different interviews that "there are echoes of Wittgenstein in his period as a schoolteacher in Austria", especially his "moral radicalism" (Schwartz 2007, 73). The Sebald narrator's self-imposed exile in the story "Max Ferber" further calls to mind Wittgenstein's early move to Manchester, while Ferber himself happens to have lodged at 104 Palatine Rd, "the selfsame house where Ludwig Wittgenstein, then a twenty-four year old engineering student, had lived in 1908" (Sebald 2002, 166).

8 "What is the use of studying philosophy ... if it does not improve your thinking about the important questions of everyday life", and his striking declaration in the Big Typescript (especially if we bear Austerlitz in mind), that "as is frequently the case in architecture, work in philosophy is actually closer to working on oneself. On one's own understanding. On the way one sees things. (And on what one demands of them.)" (Wittgenstein 2005, 300e).

${ }^{9}$ See Freud 1948. For a discussion of the uncanny in relation to Wittgenstein's work, see Schalkwyk 2004. 
stitutes an uncanny paradox. His presence registers something that is largely absent from, but may also be regarded as the crux of, Wittgenstein's own philosophical work. The real, historically based journeys of all Sebald's protagonists, in a pre-World-War-II Europe and its aftermath, embody in historical and fictional shape the governing metaphors of Wittgenstein's philosophy: the ideas that a philosophical problem takes the form "I don't know my way about"; that it is the task of philosophy to return language to its proper home; that language is like the streets of an old city along which one needs to trace and retrace one's tracks, as much by reminding oneself of what one already knows as by offering a perspicuous representation of unnoticed relations; ${ }^{10}$ and that philosophy is an ethical task of working upon oneself, in an attempt to achieve absolute honesty and the "liberating word" that will allow one to rest. Most important for Sebald, perhaps, is Wittgenstein's adherence, as Louis Sass puts it, to Nietzsche's idea that "every great philosophy is in fact 'a confession on the part of its author and a kind of involuntary and unconscious memoir"". 11 Sebald returns Wittgenstein's metaphors to the troubled, homeless world from which Wittgenstein himself came, performing in an allusive, fictional way what Ray Monk's biography achieves more directly. The tragic, haunting story of Paul Bereyter's life and death might be considered an invitation to imagine what Wittgenstein's life might have been like had he persisted with his goal of teaching primary school children amongst people with whom he felt an utter stranger. Sebald's own haunted attempts to find an ethical mode of representing the spiritual, emotional, and physical dislocation and obliteration of whole peoples and their identities in the Europe before, during and after the Nazis, turn also to Wittgenstein's philosophical methods in the novelist's quest to penetrate the darkness of his own time. Sebald takes from Wittgenstein a form of representation that eschews the

${ }^{10}$ See Seebald 2001, 174: "If language may be regarded as an old city full of streets and squares, nooks and crannies, with some quarters dating from far back in time while others have been torn down, cleared up and rebuilt, and with suburbs reaching further and further into the surrounding country, then I was like a man who had been abroad a long time and cannot find his way through this urban sprawl any more, no longer knows what a bus stop is for, or what a back yard is, or a street junction, and avenue or a bridge."

11 Louis Sass 2001, 99. 
usual kinds of causal explanation for those which involve seeing connections. The album of sketches compiled from many journeys criss-cross in every direction connects Wittgenstein's mode of working to the acknowledged strangeness of Sebald's own prose, its mysteriously evocative photographs, and the ethical complications of his characters.

All Sebald's work is an attempt to sketch a grammar of memory in its relation to the loss of home or the condition of exile. It is a tireless, if immensely burdened, quest to carry out what Wittgenstein left undone on the terrain of memory. Sebald shows his deepest affinity with Wittgenstein in his reiterated attempts to trace the concept of memory as it constitutes personal and cultural identity, indeed the very possibility of the forms of life that lie at the foundation of Wittgenstein's notion of language itselfin the attendant dislocations of exile: strangeness, alienation, longing and recovery, all encompassed by an incessant series of real journeys. Two apparently separate historical events bear the burden of the loss or repression of memory. The first is the experience of Jewish exiles, from those conveyed at a very early age from their families and homes by the Kindertransporte, like Jacques Austerlitz, or as teenagers, like Max Ferber, to the even earlier dislocations of Dr Henry Selwyn and Sebald's uncle, Ambros Adelwarth. They are exemplified for Sebald by people like Jean Améry, Primo Levi, and Paul Celan, who, as he puts it, "ultimately succumbed to the weight of memory" (Schwartz 2007, 38). The second event, which directly involves Sebald himself, is what he decries as the "conspiracy of silence" in Germany after the war - the apparently willful act of forgetting, both as perpetrators and then as victims of the allied bombing of whole German cities such as Dresden and Hamburg.

Sebald's narrator or his protagonists tell their separate stories as a process in which the strands of remembering and forgetting are almost indistinguishable. Austerlitz's life story involves a slow, infinitely painful process of gradually reliving experiences that resurface from a traumatic past, but that revival of memory leads to other forms of spiritual paralysis and loss. These recollections of experiences or memories are emphatically not under the protagonist's control. They have been repressed, although one should be very careful about reading such a process in Freudian terms. Furthermore, the memories of the protagonists are always filtered through those of the narrator, who has his own reasons for repression and excava- 
tion. Often one is not quite sure whether the memories, or the lapses of memory, being recorded are those of narrator or protagonist, since the one is so often embedded in the other: the stated memories (or lapses of memory) of his protagonist are conveyed through the narrator's explicit recollection of memory or confession of amnesia. One cannot read a sentence of Sebald's prose without being aware of the complications of memory, forgetting and the difficulties of their representation.

Sebald's work is thus as much about the ravages of forgetting as it is about the mysteries of memory. There is clearly a Freudian undertow to his sense that certain traumatic events - in each case the loss of home, parents, family, a familiar and reassuringly humane existence-leads to the repression of the very memories of such comforting childhood. Such repression is not Freudian, however, because it is not sexual but rather cultural and political, and because the return of memory offers no relief but rather further pain, which in Sebald's stories almost invariably results in suicide. Sebald's work, then, asks how memory and forgetting are related grammatically, within the context of a specific European cultural life and its history of destruction. To what degree is each a voluntary act? To what degree may each be said to be the product of thought or experience? How is each related to the unconscious, especially to the processes of repression? To what extent, for example, are Austerlitz's repressed memories of his childhood in Prague, his parents who are murdered by the Nazis, and his experience of the Kindertransporte to England and Wales comparable to Sebald's own concern with the post-war German repression of the events of the "destruction" as he puts it, in and of Europe and Germany?

The difference may seem to lie in the respective relations of victim and perpetrator to the trauma of victimhood and the evasive guilt of the perpetrator - one is inclined to say that the victim's repression is caused involuntarily by what happened to him or her, whereas the forgetting of the perpetrator stems from more conscious motives of bad faith. And yet Sebald complicates that commonsense notion by pointing to the role of the German people as victims of the horrendous allied bombings of their cities. "People's ability to forget what they do not want to know, to overlook what is before their eyes, was seldom put to the test better than in Germany 
at that time", ${ }^{12}$ he writes, alluding to the "extraordinary faculty for selfanaesthesia", and that "the almost entire absence of profound disturbance to the inner life of the nation suggests that the new Federal German society relegated the experiences of its own prehistory to the back of its mind and developed an almost perfectly functioning mechanism of repression" (1112), citing Alexander Kluge's statement that "the population, although obviously showing an innate wish to tell its story, [had] lost the psychic power of accurate memory" (24). What is striking about Sebald's writing here is the way in which it evades the decision to attribute either agency or passivity to the collective process, and thus renders problematical the question of ethics and responsibility. Forgetting what one does not want to know suggests that such obliteration of memories is conscious or deliberate, while talk of a mechanism of repression and of losing the power of accurate memory indicates a more passive, unconscious process, in which one is a victim of forces beyond one's control.

Those who have not become victims of such self-imposed forgetting face the problem of finding an adequate way of representing the traumatic events that gave rise to the amnesia. Sebald is consequently wary of any easy recourse to actual witnessing of traumatic events. He writes of the "unreal effect of eyewitness reports", which derives from the "clichés to which they often resorted" and which "cover up and neutralize experiences beyond our ability to comprehend" (Sebald 1999, 24-5). Such eyewitness accounts therefore "need to be supplemented by what a synoptic and artificial view reveals" (25-6). Such a perspective is artificial in the sense that it is not a genuine eyewitness account - it is the product of art or fiction working with "witnesses one can trust" (Schwartz 2007, 85). But, like Wittgenstein's work, the very nature of its subject precludes the achievement of a removed, synoptic viewpoint. Sebald is more accurate when he writes, "if there is such a thing as a revelation, if there is a moment in a text which is surrounded by something like claritas or veritas, then it can be achieved only by actually going to certain places, by looking, by expending large amounts of time in actually exposing oneself to places that no one goes to" (Schwartz 2007, 85). Going, looking, exposing oneselfbut also seeing connections, putting things together, making the strange

12 Sebald 1999, 41. 
familiar and the familiar strange. All of these things are encompassed in Sebald's work by the uncanny workings of memory.

Characteristically, Wittgenstein's discussions of memory are focused on the question of the degree to which remembering may be considered an experience, to what extent such an experience is the foundation of the concept of memory, and to what extent remembering provides us with the concept of the past; whether memory is a voluntary process; the relationship between remembering and aspect perception; and the affinities (or not) between remembering and cognate psychological terms like dreaming, knowing, imagining, and the experiencing of a mental image. Insofar as Wittgenstein sketches a grammar of memory, he offers two distinct notions, each differently related to the will and an experience or mental image.

We tend to think that remembering is some kind of mental experience in which images play a decisive role. But if I am asked what I have been doing for the last two hours, Wittgenstein points out, "I answer ... straight off, and I don't read the answer off from the experience I am having" ${ }^{13}$ On the other hand, I can say that I remember or recall something, and this may well involve a mental process or experience. Furthermore, I can and often do say that I believe I remember something. Such cases reveal "what is [indeed] subjective in psychology" (107). This is an important concession in the context of Wittgenstein's characteristic attack on the idea that the content of an experience provides us with a concept, especially when it is conceived as a private object to which only I have access. When does one ever need such a private, inner picture? Certainly not as the foundation of meaning, which cannot be based on a private object, because the vagaries of memory cannot ensure that one applies the same word to the same private object from one moment to another. One might always misremember-merely believe that one remembers - which means that there can be no criterion of sameness of application to sustain the repeatability of the concept as the same thing. Meaning cannot be subjective; but can memory be private and inscrutable?

This question raises questions of moment and intricate detail. For if one can always misremember then what remains to connect one moment of use with a future instance, or the past one? On what does the criterion of

\footnotetext{
${ }^{13}$ Wittgenstein 1982, 105.
} 
going on in the correct way stand, if not on the correctness of memory? Wittgenstein asks: "Does remembering teach us ... that a certain event took place in the past? - then we would have to connect it up with past events ... Whereas it is really the criterion for the past" $(L W, 837)$. This is a characteristic, Wittgensteinian move, which seeks to get rid of any mysterious, intermediate process - any kind of third entity which would have to make the link between memory and the past. Remembering, Wittgenstein seems to be saying, unlike hoping, or wishing, or imagining, is internally or grammatically, or by definition, connected to the past. Does this mean that memory is the criterion of the concept of the past-i.e. memory is of the past but not of the present or the future - or the content of the past, that such a thing did actually happen? It clearly cannot be the latter, since that would mean that the memory of a past event would be the criterion of its truth. Memories lie. So even if a memory is part of the concept of the past, it can't be internally connected to the actuality of a past event. Memory could act as dreams do, Wittgenstein suggests, "gather[ing] together a great number of memories from the preceding day, from days before that, even from childhood, and turn[ing] them into a memory of an event that took place while a person was sleeping" $(L W, 656)$.

It is especially frustrating that the very last remarks in the Philosophical Investigations should contain Wittgenstein's most enigmatic comments on memory. The role of remembering in connecting events (including those involving the meaning of the concept of memory) is offset by the dependence of the concept on something that is not merely an experience. Remembering is not the description of a present experience. Indeed, he states, "remembering has no experiential content". There is a distinction between saying, "Now I know what tingling is", when I experience an electric shock for the first time, and declaring that I know what remembering is because I have now remembered for the first time. And how, Wittgenstein asks, on the penultimate page, "will [I] know again in the future what remembering feels like" (PI, p. 231)? Is this problematic because-he leaves it unsaid - it will require memory to know?

Two points do seem to be clearly illuminating in Wittgenstein's sketch of the grammar of memory. One is Wittgenstein's suggestion that there may be two concepts of remembering: even though saying "I remember him clearly", or "I remember what I was doing last night", cannot be 
reduced to any particular experience, there are cases in which one might talk of the feeling of "Long, long ago"; more important, there is a use of the concept, when memories rise up before one's mind, for example, for which memories may well be experiences. The other is his advice that "when I say 'I remember, I believed' ... don't ask yourself 'what fact, what process is he remembering? ... ask rather, 'What is the purpose of this language, how is it being used?"' $(L W, 716)$.

How is such language used in Sebald's work? Memory is seldom of the mundane, "I remember what I was doing for the past two hours", sort. It is concerns the interrelation of the recollection and suppression of events in which both the experiential component is very powerful, and what Wittgenstein calls the "disturbance of memory", when it behaves as a dream might, condensing and displacing specific recollections, is pronounced. Acutely aware of the ethical problems what he calls "the entire questionable business of writing", that is to say, of offering an account of things and events of which he has himself no memory, and which may be said to be both unspeakable and unutterable, Sebald strangely insinuates his prose into the "emptiness", as he calls it, "that needs to be filled" (Schwartz 2007, 85 ). He has a metaphysical horror of the continuous lapsing of human experience, of "how little we can hold in mind, how everything is constantly lapsing into oblivion with every extinguished life, how the world is, as it were draining itself in that history of countless places and objects which themselves have no power of memory is never heard, never described or passed on" (Schwartz 2007, 149). But his concern is also more specifically located in his own time and place, especially in the burden he bears himself, as a member of the post-war generation (he was born in 1944), of a national amnesia: "I felt increasingly that the mental impoverishment and lack of memory that marked the Germans," he writes, "and the efficiency with which they cleaned everything up, were beginning to affect my head and my nerves" (Sebald 2002, 225).

Despite the fact that such impoverishment, lack, and its concomitant, deadly efficiency finally drove Sebald from his homeland as a young man, he nevertheless assumes the burden of making up for such moral deficiencies in his writing, acknowledging his continued connection to his homeland like an "inherited ... backpack" that he has "to carry whether I like it or not" (Schwartz 2007, 51). That backpack, which plays such a large 
symbolic role in his stories (including its allusion to Wittgenstein's visit to America towards the end of his life) is the ethical imperative of restoring and preserving repressed cultural memory. Writing, then, is a way of "remind[ing] people, because we've all seen images, but those images militate against discursive thinking, for reflecting upon these things. And also paralyze, as it were, our moral capacity" (Schwartz 2007, 80). There is an affinity with Wittgenstein in Sebald's suspicion of the image, especially its tendency to cut itself lose from its enabling relations and its imperious claims to self-sufficiency. ${ }^{14}$ Returning the image to "discursive thinking" means bringing it back into relation with things that militate against our seeing it in only one way, or seeing it with a lazy, complacent eye. Such complacency is what immobilizes our moral capacity. The recovery of memory in which Sebald engages means doing what Austerlitz vainly tries to achieve in the rearrangement of his photographs, what Sebald himself attempts in his stories of layered memory and representation, and Wittgenstein strives for through the combined making of connections and seeking of a perspicuous form of representation.

Let us begin with the problems of the first-person plural pronoun, raised in Sebald's declaration that "we have all seen images". Can one speak of a collective memory, or a collective amnesia? And can a single person restore the loss of memory of a whole community or nation? Wittgenstein would try to answer these questions by turning to the grammar of the language. But which grammar, and which language? In other words, who is the "we" that would be invoked in such an exercise, which always calls upon a more-or-less unified community of speakers, as Sebald seems to do in the interview I cite?

One of the persistent issues in Sebald's stories is the loss of a sense of community, which penetrates to the core of being. This is exemplified by Sebald's quotation of Paul Amery's account on the effect of the Nazi

${ }^{14}$ Cf. Sebald 2001, 101: "All of us, even when we think we have noted every tiny detail, resort to set pieces which have already been staged often enough by others. We try to reproduce the reality, but the harder we try, the more we find the pictures that make up the stock-in-trade of the spectacle of history forcing themselves upon us ... Our concern with history, so Hilary's thesis ran, is a concern with preformed images, images at which we keep on staring while the truth lies elsewhere, away from it all, somewhere as yet undiscovered". 
occupation of his homeland, Austria: "Everything that had filled my consciousness - from the history of my country, which was no longer mine, to the landscape images, whose images I suppressed, had become intolerable to me ... I was a person who could no longer say 'we' and who therefore said 'I' merely out of habit, but not with the feeling of full possession of myself" (Sebald 1999, 160). Amery's inability to use the first person plural in effect empties out the significance or force of the singular form. "I" depends upon the fullness of "we". On this question of the possible communal nature of memory (and its fragility) I turn to Anna Wierzbicka, who argues that an analysis of the English concepts "memory" and "remembering" would fail to offer a universal, or even a European grammar of the terms. ${ }^{15}$ For cultural and historical reasons, including the effects of an Enlightenment culture of scientific progress in combination with a political history that did not include major dislocation or exile for its native speakers, Wierzbicka suggest that the English notion of memory tends to be the personal recollection of experience as if from a storehouse. English memories are, as it were, things "'kept' in a person's head ... 'private' as if 'owned' by the person who has experienced some events" (23). This concept of memory approximates the modern, cognitive-science reduction of memory to accessible information, as when we speak of a computer's memory, and it is exemplified by the statement by editor of a recent study of memory that the concept is to be "understood broadly as the "capacity to encode, store, and retrieve information" (cf. Baddeley 1999), but also includes the inability to retrieve information (e.g. 'forget')". ${ }^{16}$ Wierzbicka argues that Polish and Russian, and even French and German, are quite different. They retain a sense of the dynamic, rather than merely factual, quality of remembering that used to be part of early modern English, but appears now to have been attenuated, as remembering has shifted from the combination of experience and thought, as in "think over something", to the recalling of specific content or "information". Wierzbicka alludes to the Proustian "il me souvient" - as it were, "it remembers itself to me" —as a quality that, like the German sich erinnern, "is less active and implies less control than the English" (26). She adduces a number of cognate terms for

15 Wierzbicka 2007.

${ }^{16}$ Amberber 2007, 1. 
memory in Polish that, as she expresses it, imply a cultural shift or difference, from retrieving information about the past to going over, or undergoing, or re-experiencing it. The Polish word, wspomnienia, for example, "implies something one has lived through", and wspominac refers to the activity of "bringing some memories to the surface of consciousness ... bring[ing] to light things that were hidden before ... creating new knowledge [or awareness] rather than activat[ing] knowledge previously stored in the mind" (30).

Wierzbicka suggests that the difference between the English sense of memory or remembering and the supposed equivalents in Polish imply "a form of life (in Wittgenstein's sense) which is not lexically recognized in English" (30). This means that a grammar of memory is different for Polish and English, and that this difference would embody the divergent ways in which what appears to be a universal human faculty is shaped by cultural and historical experience and practice. Wierzbicka points out that the Polish concept of wspomnienia encompasses a "past [that] is not a purely private past but has a historical dimension and refers to the experiences which were shared by many people" (30).

This raises crucial questions regarding the grammar of memory. Is memory like the concept of pain, which only I can have (which means, in the strictest sense that I cannot be said to have it at all), or is it closer to the concept of perception which I can share with others (assuming that perception is not reducible to the private experiences of sense data)? Wittgenstein reminds us: "It might not strike us as so much a matter of course that memory shows us the past inner, as well as the past outer, process". ${ }^{17} \mathrm{Just}$ as it may be said that no-one else can have my memories, it can also be said that my memories are of events which others remember too, and which they may remember more accurately or more completely than I do. "Memories" may imply an inner process, whereas "I remember" does not. As Wierzbicka puts it, "Remember implies knowledge which has its source in personal experience, but it doesn't have to be knowledge of something that happened to me: what happened to me is the source of knowledge, not its content. In the case of 'memories' it is both source and content" (23). Not only is this notion foreign to the idea of the storage of information, but

${ }^{17}$ Wittgenstein 1980, 847. 
it also encompasses a conception of communal memory which may be imbedded in the relationship of a language to the historical experiences of its people. Wierzbiecka points out that the salient features of Polish history may explain the difference between the English and Polish semantics of memory: "a history of partitions, deprivation of national independence, threat to national identity, uprisings, exile, mass deportations, forced emigration, and throughout all that, a cultivation of national memory" (31).

The subjects of Sebald's stories are the participants in and victims of precisely such partitions, deprivations, threats, exile, forced emigration, and worse. Not only is remembering and forgetting for them more than a mere matter of retrieving or losing information, it is also connected with another concept upon which Wierzbicka focuses in her analysis of the different cultural lexicons of memory. That concept is represented by the word pamiatka - the diminutive of the word for memory: pamiecc. Such a "little memory" would be translated, very inadequately, by the English phrase "heirlooms", or perhaps "memento" or "souvenir". These are objects of intense affective value, which continue to carry memory despite dislocation, exile, or the destruction of home and family ties. The word "also seems to suggest" Wierzbicka writes, "an appreciation that the framework of one's life can be destroyed, that the continuity of this framework cannot be taken for granted, and that since the material links between the present and the past are likely to be fragile and limited, they should be an object of special care and devotion (almost veneration, like relics)" (33). One of the most haunting moments in Austerlitz occurs when the protagonist, on a visit to Terezín, where his parents were certainly interned and met their end, comes across a shop window, revealing a vast collection of household objects. These objects

exerted such a power of attraction on me that it was a long time before I could tear myself away from staring at the hundreds of different objects, my forehead pressed against the cold window, as if one of them or their relationship with each other must provide an unequivocal answer to the many questions I found it impossible to ask in my mind. What was the meaning of the festive lace tablecloth hanging over the back of the ottoman, and the armchair with its worn brocade cover? What secret lay behind the three brass mortars of different sizes, which had about them the suggestion of an oracular utterance, or the cut-glass bowls, ceramic vases and earthenware jugs, the tin advertising sign bearing the words Theriesenstädter Wasser, the little box of seashells, the 
miniature barrel organ ... And then there was the stuffed squirrel ... which had its beady implacably eye fixed upon me and whose Czech nameveverka-I now recalled like the name of a long-lost friend. What, I asked myself, said Austerlitz, might be the significance of the river never rising from any source, never flowing into the sea, but always back into itself, what was the meaning of veverka ... or the porcelain group of a hero on horseback turning to look back ... in order to raise up with his outstretched left arm an innocent girl already bereft of her last hope, and to save her from a cruel fate not revealed to the observer? They were all as timeless as that moment of rescue, perpetuated but for ever just occurring, these ornaments, utensils and mementoes stranded in the Terezín bazaar, objects that for reasons one could never know had outlived their former owners and survived the process of destruction, so that I could now see my own faint shadow image barely perceptible among them. (Sebald 2001, 275-7)

In her comments about the difference between "souvenir" and pamiatka, Wierzbicka states that the former "evokes freedom of movement and facility of travel" whereas the Polish word "evokes transience of life, loss and destructibility of the past ... it is an object which links the present with the past, and which enables the past to live on in people's thoughts and emotions" (33). It is clear from Sebald's description of the objects from Terezín that this work of memory does not belong to any specific kind of object; rather it depends upon how an object is related to others, or to the lives of those who lived with it, and used it. What is so desperately moving about Austerlitz's encounter is his sense that whatever memories or significance the mass of possessions in the shop window have or had, it is inscrutable, lost or forgotten, and moreover, that that loss wrenches him away from himself. The emotional ties and intensity that such objects indubitably once had by virtue of being woven into the lives of their owners has ebbed away, leaving only Austerlitz's isolated questions and longing, an attenuated connection exemplified by Austerlitz's discernment of his "own faint shadow image barely perceptible among" the articles.

This moment is echoed to even more devastating effect at the end of the novel, when on a visit to the Bibliothèque Nationale, Austerlitz is made aware of the fact that the library is built on the ruins of an immense warehouse where the Nazi's had collected and then redistributed the possessions that they had looted from the "homes of the Jews of Paris" (401) "In the years from 1942 onwards, everything our civilization has produced, 
whether for the embellishment of life or merely for everyday use, from Louis XVI chests of drawers, Meissen porcelain, Persian rugs and whole libraries, down to the last salt-cellar and paper-mill, was stacked in the Austerlitz-Tolbiac depot ... no one will admit to knowing where they went, for the fact is that the whole affair lies buried in the most literal sense beneath the foundations of our Pharaonic President's Grande Bibiliotèque..." (402-3). The objects described in Sebald's novel are thus aligned with Wierzbecka's analysis of the investment of a communal memory under conditions of loss and separation, but they have, as it were, been emptied of any specific memories and stripped of their human relations: they have become inscrutable husks whose "meanings", "secrets" and "significance" have not merely ebbed away, as all memory appears to for Sebald, but been violently taken away and horribly redistributed among the perpetrators as in the Austerlitz warehouses in Paris. It is like cutting up the victims themselves and sharing them out, or parcelling out bits of their souls.

In her analysis of the different place and concepts of memory in European languages, Wierzbicka suggests that German lies somewhere between Polish and English insofar as it also registers memory as a collective process of living through. It is not so much a voluntary retrieval of information, as an undergoing or re-experiencing or reliving of a past that is not reducible to the retrieval of information or images. My German is not good enough register such nuances in Sebald's prose. I am therefore speculating when I suggest that the strange, uncanny effect that Sebald has on English readers may have something to do with the way in which his writing conveys something of this different grammar of memory to English. Sebald's prose may convey syntactically rather than semantically a different form of life pertaining to the grammar of memory and its relation to historically and culturally specific forms of life that are in effect foreign to or not at home in English. Its power may thus lie in the way in which, as many translations do, it expands and enriches the conceptual possibilities of its target language, thereby rendering it receptive to different modes of cultural or historical existence, or the uncovering of traces of repressed histories and experiences. This quality may account for the haunting strangeness of Sebald's prose in English. Its sense of not quite being at home embodies in the most powerful, if subtle, ways the very substance of its modes of representation: Jacques Austerlitz's dislocation from a privileged, 
middle-class, Jewish childhood in Prague to an insular, oppressive, Presbyterianism in working-class Wales; Max Ferber's move from the social world of artistic consumption and trade in pre-war Munich to that of the isolated artist in the depressed Manchester of Jewish migration; and even Sebald and Wittgenstein's own repective exiles from a superficially homely existence in Germany and Austria to the oddity of academic life in provincial England.

I want to end by looking at Ruth Franklin's criticism of Sebald for presuming to make up for lost memory through the artifice, or what she terms the "illusion", of his art (Schwartz 2007, 142). The gaps of which Sebald speaks are, she claims, "gaps in literature, not gaps in memory ... Gaps in memory are experience that is forever lost, and art cannot take its place" (Schwartz 2007, 141). Many critics have commented on the image at the very end of The Emigrants. the description of a photograph of three young women sitting behind a spinning loom in the Polish ghetto known by the Nazis as Litzmanstadt, whose names have been lost, even if their fates can be assumed with horrible certainty: "I wonder what these three women's names were-_," Sebald's narrator muses, "Rosa, Luisa and Lea, or Nona, Decuma and Morta, the daughters of the night, with spindle scissors and thread" (Sebald 2002, 237). Franklin responds by saying, of her own grandmother who disappeared in such a ghetto, "I do not know what she looked like as a young woman ... but my imagining her behind Sebald's loom ... merely substitutes an artistic image for a blank space. The blankness, however, is closer to the truth" (Schwartz 2007, 142). This is a powerful, and moving, critique. Franklin is, of course, making a grammatical observation about the difference between memory and imagination, and the ethical dangers of confusing the two: "We appreciate the beauty of the image that the writer discerns, but it adds nothing to our understanding of why things happened as they did" (140).

The question is, as it is for Wittgenstein, whether Sebald is trying to provide a causal explanation of historical events - "of why things happened as they did" (Schwartz 2007, 142). This brings us to Sebald's deepest affinity with the Wittgenstein. The last thing that Sebald attempts to do in his writing is to provide explanations or to recapture the, to him, dubious value of an purely eyewitness notion of "truth". Hence Wittgenstein's statement that such accounts (he does not reject them altogether) need to be 
"supplemented by what an artificial and synoptic view reveals" (Seebald 1999, 26). In the light of Franklin's claim that art may lead to illusion, we can now recognize the force of Sebald's emphasis on the "artificial" qualities of such a view, and I hope that it is now clear how Sebald's desire for a synoptic perspective recalls Wittgenstein's similar quest.

The synoptic view is the one which enables one most clearly to see connections without offering a causal explanation (for example of what memory and forgetting are, or why people invest so much of themselves in the objects they possess). But such a view from above, for which one needs a ladder or has to leave the roughness of the world entirely, is extraordinarily difficult, if not impossible, to achieve. Wittgenstein and Sebald are both condemned to ceaseless journeys in order to recover the home that is "our" language or memory, both of which, insofar as they are "ours", lie between the singular and the plural of the first-person pronoun. ${ }^{18}$ Such travels in both cases produce an album of sketches that can be arranged and rearranged, like Austerlitz's photographs, in various combinations, until one finds what Wittgenstein calls the "liberating word ... the word that finally permits us to grasp what until then had constantly and intangibly weighed on our consciousness" (BT, 302e). They provide neither a unified picture of the world, nor an explanation of why it is as it is. Wittgenstein's Remarks on Frazer's “Golden Bough” are especially apposite:

It is the multiplicity of faces with common features which continually emerges here and there. And one would like to draw lines connecting these common ingredients. But then one part of our account would still be missing, namely, that which brings this picture into connection with our own feelings and thoughts. This part gives the account depth. ${ }^{19}$

His modes of fiction allow Sebald to layer the making of connections, both in the relations among the events of experience and the processes of such narration, in which memories of narrator and protagonist overlap. Such narrative procedures produce both the possibilities of communal memory and invite us to bring those relationships "into connection with our own thoughts and feelings". Sebald shows that memory is like aspect seeing, an

\footnotetext{
${ }^{18}$ See Schalkwyk 2004.

${ }^{19}$ Wittgenstein 1993, 143.
} 
echo of thought in an experience that is both, as Wittgenstein puts it, an inner and an outer process.

Sebald states that "for those whose business is language, it is only in language that the unhappiness of exile can be overcome" (Sebald 1999, 161). Of course, language is the business of all human beings. That is why Wittgenstein (and Sebald for that matter) can hold both that grammar depends upon specific forms of life and also that it is worth bringing the practices of people who seem removed from us into connection with our own thoughts and feelings. But the issue of what counts as "our own" always remains open. The question is whether the unhappiness of exile, insofar as it is registered in language, can be overcome. Wittgenstein, it appears, did not find any single "liberating word that finally permits us to grasp what until then had constantly and intangibly weighed on our consciousness". There is no finally. Only a ceaseless process of traversing the places of memory and forgetting, not so that they can be explained, but so that they can be relived and clarified, in a world bit by bit brought a little closer to home.

\section{Literature}

Amberber, Mengistu 2007: "Introduction". In: Amberber, Mengistu (ed.): The Language of Memory in a Cross-linguistic Perspective. Amsterdam / Philadelphia: J. Benjamins.

Freud, Sigmund 1948: “The Uncanny". In: Collected Papers, Vol. 4, trans. Joan Riviere. London: The Hogarth Press.

Perloff, Marjorie 1999: Wittgenstein's Ladder: Poetic Language and the Strangeness of the Ordinary. Chicago: University of Chicago Press.

Sass, Louis 2001: "Deep Disquietudes: Reflections on Wittgenstein as Antiphilosopher". In: Klagge, James C. (ed.): Wittgenstein: Biography and Philosophy. Cambridge: Cambridge University Press.

Schalkwyk, David 2004: “Wittgenstein's 'Imperfect Garden': The Ladders and Labyrinths of Philosophy as Dichtung". In: Gibson, John / Huemer, Wolfgang: The Literary Wittgenstein. London / New York: Routledge, 55-74.

Schwartz, Lynne Sharon 2007: The Emergence of Memory: Conversations with W.G. Sebald. New York: Seven Stories Press. 
Sears, John 2007: "Photographs, Images, and the Space of Literature in Sebald's Prose". In: Patt, Lisa (ed.): Searching for Sebald: Photography after W.G. Sebald. Los Angeles: The Institute for Cultural Inquiry.

Sebald, W. G. 1999: On the Natural History of Destruction, trans. Anthea Bell. New York: The Modern Library.

Sebald, W. G. 2001: Austerlitz, trans. Anthea Bell. Penguin: Harmondsworth.

Sebald, W. G. 2002: The Emigrants. New York: Vintage.

Stern, David 2001: “Was Wittgenstein a Jew?". In: Klagge, James C. (ed.): Wittgenstein: Biography and Philosophy. Cambridge: Cambridge University Press.

Wierzbicka, Anna 2007: 'Is 'remember' a universal human concept? 'Memory' and Culture". In: Amberber, Mengistu (ed.): The Language of Memory in a Crosslinguistic Perspective. Amsterdam / Philadelphia: J. Benjamins, 13-39.

Wittgenstein, Ludwig 1953: Philosophical Investigations, trans. G.E.M. Anscombe. Oxford: Blackwell. $(P I)$

Wittgenstein, Ludwig 1980: Remarks on the Philosophy of Psychology, Vol. 1, ed. G.E.M. Anscombe and G.H. von Wright, trans. G.E.M. Anscombe. Oxford: Blackwell.

Wittgenstein, Ludwig 1982: Last Writings On The Philosophy Of Psychology, Vol. 2, ed. G.H. von Wright and Heikki Nyman ; trans. C.G. Luckhardt and Maximilian A.E. Aue. Chicago: University of Chicago Press. $(L W)$

Wittgenstein, Ludwig 1991: Geheime Tagebücher: 1914-1916, ed. Wilhelm Baum. Wien: Verlag Turia \& Kant.

Wittgenstein, Ludwig 1993: Philosophical Occasions 1912-1951, ed. James C. Klagge and Alfred Nordmann. Indianapolis; Hackett.

Wittgenstein, Ludwig 2005: Big Typescript TS. 213, ed. C. Luckhardt and Maximillian Aue. Malden, MA: Blackwell. (BT) 